\title{
Young Rebels Who Do Not Want a Revolution: The Non-participatory Preferences of Fridays for Future Activists in Finland
}

\author{
Janette Huttunen ${ }^{1 *}$ \\ ${ }^{1}$ Faculty of Social Sciences, Business and Economics, Åbo Akademi University, Turku, Finland
}

OPEN ACCESS

Edited by:

Matt Henn,

Nottingham Trent University,

United Kingdom

Reviewed by:

Roger Soler-i-Martí,

Pompeu Fabra University, Spain

Bernd Bonfert,

Cardiff University, United Kingdom

*Correspondence:

Janette Huttunen

janette.huttunen@abo.fi

Specialty section:

This article was submitted to

Political Participation,

a section of the journal Frontiers in Political Science

Received: 25 February 2021 Accepted: 23 April 2021

Published: 10 May 2021

\section{Citation:}

Huttunen J (2021) Young Rebels Who Do Not Want a Revolution: The Nonparticipatory Preferences of Fridays for

Future Activists in Finland.

Front. Polit. Sci. 3:672362.

doi: 10.3389/fpos.2021.672362
Young people's lack of participation in elections has been taken as a sign that the young are wary of representative democracy and reject traditional authorities. Instead of election participation, it is expected that the young want more possibilities for direct involvement in political decision-making. Fridays for Future (FFF) is a global, youth-led climate movement that has been able to mobilize millions of young people around the world into political action (de Moor et al., 2020; Wahlström et al., 2019) in times when youth participation is generally declining, especially in traditional forms of political participation. While many have taken this as evidence that young people dismiss representative democracy in favor of a more participatory democracy, in-depth studies of their motivations are still lacking. This article helps fill this lacuna by providing a case study on Finnish FFF participants. Through semistructured interviews and theory-guided content analysis with 15- to 20-year-old climate activists, the Finnish FFF participants' attitudes toward political participation are examined. The data consists of 11 one-on-one in-depth theme interviews with young people, who participated in the FFF movement by attending at least one protest in Finland in 2019. The interviews focused on the following themes: motivation for participation in the FFF movement, interviewee's background, and the participant's ideas regarding politics, democracy, and political participation. The interviews were combined with material from various news sources to contextualize the information in the analysis phase. Based on the empirical evidence, I argue that although these young citizens have become politically active in a climate protest movement, it does not necessarily mean that they want major reforms to the representative democracy toward a more participatory system. Instead of more participatory possibilities, the Finnish climate activists want a better-functioning representative system with politicians who listen to their demands.

Keywords: youth participation, fridays for future, political participation, single-issue movements, qualitative methods

\section{INTRODUCTION}

In the fall of 2018, 15-year-old Swedish activist Greta Thunberg held a one-person protest outside of the Swedish parliament and started the global climate movement 'Fridays for Future' (FFF). Fridays for Future is a modern climate protest movement consisting largely of school students, who use civil disobedience in the form of school strikes to protest inadequate climate actions taken by politicians. 
The movement demands political leaders to take action in the fight against global warming and has been successful in mobilizing the young masses into protest, gain substantial amount of media-coverage, and a wide, global scope, with climate strikes organized around the world (Wahlström et al., 2019; de Moor et al., 2020).

Since young people often participate less in institutionalized politics (e.g., Furlong and Cartmel, 2007; Bennett, 2008; Grasso et al., 2018), it is important to examine cases when young people do engage in politics to understand their attitudes regarding political participation. This article provides a case study on young FFF activists in a country where the movement has been active since its early stages, Finland. I examine the Finnish climate activists' attitudes toward democracy and political participation, with the goal to shed a light on whether the young people who have become active in a mass youth movement want more participatory possibilities for their political engagement, as is often expected (see e.g., Inglehart, 1997; Dalton, 2008; Chou, 2017). In the context of this article, the concept 'participatory' refers to the idea of more direct and active citizen participation in political activities outside of the institutionalized forms of political engagement.

Studies examining people's ideas of democracy and politics rely usually on mostly quantitative data, which can be problematic when studying the young, because in surveys, what is defined as 'politics' and 'political participation' usually stem from an adult-centric perspective (see O'Toole et al., 2003; Farthing, 2010). Since young people may have a different view of what consists as political compared to older people, we might ignore vital parts of the overall picture if we only rely on survey data. Preferences for democracy are complex issues that are difficult to translate into survey questions, since most surveys only allow respondents to evaluate how the current system is working without inquiring about possible alternative decisionmaking procedures (Bengtsson, 2012). The significance of youthled conceptualization is also noted e.g., by Pontes et al. (2018), who highlight the importance that "the acts that they [researchers] consider to represent political engagement are likewise considered as political engagement acts by a younger audience."

The type of political structures citizens want are altogether an understudied subject, especially in regards to current young people and we therefore know very little about their expectations for democracy. To some extent, this is because young people constitute a small proportion of respondents when examining similar questions with data from surveys representative of the general population. This article therefore contributes to the research field by using a qualitative approach and data collected with semi-structured interviews with young FFF participants in Southern Finland. By using interviews, it is possible to give the young activist the freedom to conceptualize what democracy, politics, and political participation is for them and to study these questions from a more youth-led and open perspective.

Based on the interviews, I argue that although the Finnish FFF participants have become politically active in a climate protest movement, it does not necessarily mean that they want to see major reforms of the representative democracy toward a more participatory system. Instead of more participatory possibilities, the Finnish young climate activists want a better-functioning representative system with politicians who listen to their demands.

This article is structured as follows: first, a literature review regarding youth participation is provided. Thereafter, the case study of the FFF movement and Finland is discussed. Then, the research design is presented, followed by the analysis part, where the Finnish FFF activists' ideas of participation and democracy are discussed. Lastly, a discussion based on the analysis is provided.

\section{LITERATURE REVIEW: YOUTH POLITICAL PARTICIPATION AND IMPLICATIONS FOR DEMOCRACY}

Studies show that young people are less active in core representative institutions such as elections and political parties (e.g., Chou, 2017; Grasso et al., 2018). One interpretation of the developments in youth political engagement contends that young people do not want to be more active in democracy. Participation in general is hard and it requires cognitive skills to fathom complex political matters, which young people often still need to develop (Stoker, 2006, p. 151). Instead of political participation, individualized young citizens are more likely to abstain from politics and focus on other issues more relevant to their lives, such as education, entering the work force, or starting relationships.

However, a plethora of research on youth participation explain the development in a different way. What I here term the participatory perspective, is arguably the most popular perspective in contemporary research on youth participation within political science. Scholars within this field contend that young people today have developed more participatory norms and they therefore reject the traditional representative democratic structures (see e.g., Inglehart, 1997; Dalton, 2008, 2016). Consequently, young citizens' apparent lack of engagement in the traditional institutions of politics does not signal political apathy: on the contrary, young people are involved in political matters, but they participate in different ways than older generations do. Several studies investigating youth participation contends that the decline in electoral participation and party membership (e.g., Furlong and Cartmel, 2007; Bennett, 2008; Grasso et al., 2018), is evidence of a shift in young people's participation habits (e.g., Inglehart, 1997; Dalton, 2016; Chou, 2017; Pickard, 2019; Huttunen and Christensen, 2020). Instead of merely showing their opinions on the Election Day, young people participate in myriads of ways between elections, e.g., in single-issue movements, social movements, through ecological consumption and online activism, and they have a broader view of political participation than previous generations. This entails a need to reconfigure and broaden traditional definitions of political participation (e.g., O’Toole et al., 2003). 
The shift in youth participation is due to various societal, economic, and political changes. Inglehart's post-materialism theory (1997), which seemingly provide a suitable explanation for why we observe such developments in the participation habits of younger generations, explains that rising material well-being after WW2 led to societal change from material to post-material priorities in Western societies, which have transformed expectations and attitudes regarding political participation across generations. According to the post-materialism theory, young people differ from older generations in their habits regarding political engagement: the young expect more participatory and elite-challenging forms of political engagement. Rising education levels combined with easier access to political information strengthen citizens' abilities, or at least their belief in these abilities, to make independent political decision without interference from political elites (Dalton et al., 2001; Dalton, 2007). Building on Inglehart's post-materialism theory, Dalton explains that young people's political engagement is affected by their ideals and expectations regarding democracy, and their views on what "good" citizenship entails (see e.g., Dalton, 2016). Citizenship is defined by Dalton (2008, p. 78) as a shared set of social norms and expectations about citizens' role in politics and consequently, citizenship views have implications for political engagement since they express norms of political action. Young people foster a more engaged norm on citizenship, which increases self-expressive values as well as the ability and desire to participate more directly in the decision affecting one's life, in an elite-challenging way when necessary (Dalton, 2008; Dalton, 2016). Instead of filling a citizen duty, by e.g., voting, Dalton's theory suggests that the young want to participate in more engaged and active ways in politics by, for example, working with public interest groups, contacting politicians directly or through political consumerism (2008, p. 85).

In addition to value changes, reasons for the shift in youth participation can be sought from the political system. Pickard (2019) argue, "many young people are turning to non-electoral forms of political participation because they are disillusioned and disappointed with electoral politics, which generally fails to engage with them" (Pickard, 2019, p. 375). Many young people feel alienated from traditional politics (e.g., Henn et al., 2002; Stoker, 2006; Quintelier, 2007), and many young people have a negative view of politicians and political parties (Chou, 2017; Pickard, 2019). When electoral politics generally fail to engage the young (see e.g., Cammaerts, 2012; Pickard, 2019), young people turn to other forms of political engagement in order to get their voices heard. The young are active in wide range of non-electoral forms of political participation that covers a wide range of themes (see e.g., 'Do-It-Ourselves' politics by Pickard, 2019, p. 256). Their political activity range from directs actions and campaigns to boycotts. Young people are more causeoriented in their participation habits: their political activity is based on a particular cause or issue and they let the cause determine how to participate and they are more interested in single-issue movements as a channel for their political activity (Kimberlee, 2002; Chou, 2017). They also make use of democratic innovations such as the citizens' initiative (Huttunen and
Christensen, 2020). The rising educational levels as well as changes in society have led to young people having various capitals that enables them to act politically in various forms of political participation (Pickard, 2019, p. 375). Different forms of non-electoral political engagement expand the repertoire of political participation and young are both initiators and early adopters of such politics (Chou, 2017; Pickard, 2019, p. 377, p. 17). Instead of ideologies, specific post-materialistic issues, e.g., environmental protection or concerns over inequalities in society, mobilize them. When issues instead of ideologies mobilize the young into participation, political participation becomes more episodic and dependent on current events rather than a constant ongoing stream of political engagement, embodied by e.g., party activities. New digital technologies have also enabled young people to participate politically in a broader range of activities online (Pickard, 2019, p. 375).

In contrast to the participatory perspective, an opposite perspective on youth participation is plausible. What I here term the stealth perspective is a collection of ideas that are more skeptical of the active participation of the young. According to the participatory perspective, young people are more likely to favor high levels of citizen participation in different forms of political engagement outside of the institutionalized forms of politics, and they are likely to view participation as inherently valuable and important (Inglehart, 1997; Dalton, 2016). However, even when the young do participate in the more engaged, cause-oriented or single-issue forms of political engagement, and display political activity outside of the formal political structures, they might not necessarily do so because they are unhappy with the current representative system and want to transform fundamentally the functioning of representative democracy. There are myriad of reasons for participation. Many young people feel alienated from traditional politics and the political process (Henn et al., 2002; Stoker, 2006; Quintelier, 2007), many young people have a negative view of politicians and political parties (Chou, 2017), and they are disillusioned and disappointed with electoral politics (Pickard, 2019). There are systematic biases and different disincentives for political participation that could explain why young people are abstaining from formal politics (Chou, 2017) and putting their political engagement in other forms, such as single-issue movements, even when they do not fundamentally demand more participatory political processes. Therefore, youth mobilization in single-issue movements, cause-oriented politics, or other forms of more participatory political engagement, does not automatically equal a desire for more opportunities for citizen participation in general. Young people might state in surveys that they want more opportunities for citizen participation, but survey responses are always limited to what we ask the respondents-if there is no other way to express dissatisfaction with the representative system than by choosing more participation over representation, the results might not reflect people's real preferences (e.g., Hibbing and Theiss-Morse, 2002; Bengtsson, 2012).

Rather than an inherent desire for more citizen participation in the political processes, youth mobilization can be driven by the fear that the existing system and established actors fail to respond 
adequately to their concerns. This sentiment is reflected in Stealth Democracy, where Hibbing and Theiss-Morse argue that Americans' strongest political goal is to take power away from self-serving politicians (2002, p. 130). Crucially, this goal does not mean that people want more options for active citizen participation for so-called ordinary citizens, rather they want a system where elected representatives are fair and knowledgeable of citizens' wishes (Hibbing and Theiss-Morse, 2002). Even though citizens do not want to participate in politics, they might take an active role to take power away from self-serving politicians (Hibbing and Theiss-Morse, 2002, p. 130) or they want to be able to participate when they see that a political decision has a direct effect on them (Stoker, 2006, p. 150). When applying the stealth perspective on youth participation, mobilization among the young occurs not so much because younger generations are more participatory in their preferences for political processes in general, but because they believe that politicians fail to consider the interests of the young.

In addition to these two perspective on youth participation within the political science field, as the case study (explored further below) operates with young people who are active in the FFF movement, it is necessary to discuss perspectives from social movement studies. Social movement studies suggest that participation in social movements do not necessarily or automatically mean that the activists' want to change the existing political structures. Rather, social movement studies operate under the assumption that activists try to act in the existing democratic processes and primarily demand changes in the policy-making processes, as e.g., the 'political opportunity structure' theory (see e.g., Kriesi, 2004; Cammaerts, 2012) explains. Kriesi (2004) suggests that social movement activists have learnt to employ different types of collective actions that are increasingly overlapping with actions used by more institutionalized groups, which can contribute to an "increasing integration of social movement actors into the policymaking process" (2004, p. 85). As political opportunity structures, which are out of activists' control, affect the expectations of whether different collective actions taken by activists are successful or not (Cammaerts, 2012), engagement in certain types of activities can be more reflective of the opportunities for participation rather than a reflection of actual preferences for specific forms of participation. Environmental movements in particular have often developed close links to institutionalized politics, as the movements themselves have had strong tendencies toward institutionalization, characterized both by the internal process of professionalization and formalization but also regular access to policy-makers (see e.g., Thörn and Svenberg, 2016). Climate movements tend to demand responsibility at the political level, and are thus motivated to influence political leaders (Thörn and Svenberg, 2016).

Within the FFF movement, previous studies suggest competing ideas regarding democracy and political participation. In Germany, the movement has brought climate change to the forefront of the political agenda without challenging the underlying rationales behind climate actions nor contesting the established climate change measures, thus working closely linked to the institutionalized politics, despite the existence of more radical subgroups in the movement (Marquardt, 2020). In Britain, on the other hand, the young activists state to be committed to reaching significant change in the power structures of society through non-violent direct action, as their demands do not operate within the borders of existing systems (Pickard et al., 2020). Next, the Finnish case study is presented.

\section{THE CASE STUDY}

This article contributes the research field of youth participation by examining the Finnish FFF participants. I examine the attitudes regarding political participation and democracy that the young climate activists who have participated in the FFF movement in Finland in 2019 foster.

The FFF movement has grown into a global phenomenon not only in the environmental field, but also in regards of mass youth participation. In March 2019, an international FFF climate protest mobilized over 1.6 million (Wahlström et al., 2019), and in September 2019 over 7.6 million (de Moor et al., 2020), people around the world to protest global warming. The movement has been particularly successful in engaging young first-time participants-a study on the global climate march on March 15th' 2019 revealed that the average figure for first-time participants among school students was at around 38\% across all countries studied (Wahlström et al., 2019).

Finland is a neighboring country to the movement's birthplace Sweden, and is among the first wave of countries where the movement spread in 2018. The Finnish political system is predominantly based on representative principles, and even young people tend to have a rather conservative and traditional view on politics and for example rank voting as the best way to influence politics (Myllyniemi, 2014). However, the FFF movement has been successful in mobilizing young people in Finland since fall 2018. In September 2019, during the international climate strike, as many as 16,000 people according to some estimates participated in the main demonstration in Helsinki, with smaller demonstrations organized around the country.

The Finnish parliament elections were held in spring 2019 and climate change was one of the main issues in the elections. After the elections a new leftish-green government, which emphasizes the urgency of climate actions in its governmental program, was formed, replacing the previous conservative government. Thus, exploring the Finnish FFF activists at this time provides a possibility to explore how these young activists see political participation and democracy when the political context and leadership are seemingly favorable for their demands.

Examining the FFF movement in Finland provides also an excellent opportunity to explore whether the type of assumptions we have on youth participation, especially regarding their desire for more citizen participation, hold true when the young activists are interviewed in-depth, in a country where the young should have a multifaceted concept of democracy that goes beyond representative structures. Despite the strong focus on the representative system and the more traditional views held by the young (Myllyniemi, 2014), Finland has made use of different participatory innovations that have been introduced within the institutional realms of political participation. Most prominently, a national citizens' initiative has been available for citizens over 18-years-old since 2012, and has been 
actively used by the young millennial generation (Huttunen and Christensen, 2020). Furthermore, various democratic innovations such as mandatory youth councils at the local level, makes it plausible that young people are aware of the different opportunities to participate between elections. Additionally, research on citizens' general political process preferences in Finland shows that the population in general holds multidimensional preferences for how political decisions should be made (e.g., Bengtsson and Mattila, 2009; Bengtsson, 2012; Bengtsson and Christensen, 2016). Therefore, the Finnish climate activists operates in a context where their ideas regarding political participation and democracy should not necessarily be limited to the traditional realms of politics. In the following, I outline how the perceptions of the youth activists were examined.

\section{MATERIALS AND METHODS}

In order to further our knowledge of youth preferences for political engagement, there is a need for more qualitative approaches that allow us to research the question without the limitations of a survey with pre-defined questions and answer alternatives. As Pontes et al. (2018) showed in their study, when qualitative methods are used it is possible to derive a more youth-led definition of political engagement. This case study aims to provide perspectives on the ideas that Finnish young people who participate actively in a global environmental movement have on democracy and participation.

Quantitative studies have presented a clear picture of the sociodemographic background of the typical climate activist: she is female, educated, and young (Wahlström et al., 2019). ${ }^{1}$ The goal of this study is to deepen the understanding of young climate activist ideals and expectations for democracy by using semi-structured interviews and qualitative content analysis. The methodological choice is made in order to gain a deeper understanding of how the climate activists justify and explain their activism. Statistical methods make generalizations possible, but this is not the only suitable goal in research-sometimes a closer look at issues are necessary when there is a need to answer questions that we do not necessarily know to ask in surveys (see George and Bennett, 2005).

Qualitative methods are used to answer questions about experience and meaning, usually from the perspective of the participants (Hammarberg et al., 2016). These type of case studies are preferable to quantitative studies when conceptual validity is essential. Through in-depth interviews with participants, it is possible to let the young respondents express their experiences and ideas in their own terms (O'Toole et al., 2003, p. 74). By asking open-ended question in interviews-thereby leaving the conceptualization to the respondents-it is possible to identify how respondents themselves think about the topics (George and Bennett, 2005). As argued by e.g., (O'Toole et al., 2003), using surveys in youth studies might lead to under-reporting of political engagement because of how the surveys questions are interpreted by respondents. By using a qualitative approach, this can be avoided

${ }^{1}$ Although the median age of FFF protesters increased over time, young people still constituted a large bulk of the climate strikers (de Moor et al., 2020). and a deeper understanding of their underlying motivations can be established (see e.g., Pickard, 2019; O'Toole et al., 2003).

The gathered data used in this article consists mainly of oneon-one in-depth theme interviews with 11 Finnish 15-20-yearolds, ${ }^{2}$ who participated in the Fridays for Future (FFF) movement by attending at least one protest in 2019. These interviews were combined with material from various news sources to contextualize the information. The focus was on adolescents, young people turning into adults who are facing their first political experiences, since political experiences that happen during formative years have a great importance for later life's political attitudes and behavior (e.g., Carpini, 1989; Dinas, 2013; Quintelier and Van Deth, 2014; Delli).

Since the FFF movement is an open grassroots level movement with a low level of organization, it presented a challenge to find people who were willing to be interviewed. The respondents were identified from multiple source; through social media with hashtag \#ilmastolakko ('climate strike'), during the international climate strike in September 2019, and through respondents' recommendations for other possible interviewees through snowball sampling. This multiple sources approach made it possible to locate both more active participants in the movement as well as people who had participated only once, therefore allowing a broader spectrum of participants and a more accurate picture of the average FFF participant. To arrange the interviews, the respondents were contacted through social media (Instagram, Twitter, Facebook), and via e-mail. ${ }^{3}$

There were 11 interviewees, of whom 7 were women and 4 were men, which follows the general gender division in the movement (Wahlström et al., 2019; de Moor et al., 2020). The number of interviewees was settled to 11 , as the data felt saturated at that point since the interviews tended toward repetition (e.g., Hammarberg et al., 2016). The most important selection variables ${ }^{4}$ used in the selection of interviewees were age and participation in the strikes: four of the interviewees were active members of the FFF movement, ${ }^{5}$ while eight had participated on the strikes once. All of the interviewees were from Southern Finland. The interviews were conducted between May 2019 and October 2019. All respondents were interviewed in person by the

${ }^{2}$ The Finnish national board on research integrity (TENK) guidelines state that when studying children of the age of 15 and above, their own consent is sufficient to conduct the study, therefore the age limit for the respondents were set on 15. All respondents were informed about their rights regarding the interviews and research both in person and in written form, in a manner that a minor can understand (TENK, 2013).

${ }^{3}$ Seven possible respondents declined the interview.

${ }^{4}$ Additional information about the interviewees: five out of 11 were under 18 years of age (i.e., minors). Majority of the interviewees were educated or on a path toward higher education: nine out of 11 interviewees were either in high school or in university. From the interviewees five out of 11 did not report being active in any societal or political organizations, while six reported activity in such organizations. Out of the six, three reported being active in a political organization. Five were from a municipality with less than 100,000 inhabitants, two from a municipality with less than 150,000 inhabitants and four from a bigger city (including the capitol region). ${ }^{5}$ Active membership is here defined as all participation in the movement's activities that exceeds involvement in one strike. 
same interviewer; the interviews were recorded and then transcribed.

The interviews focused on the following themes: motivation for participation in the FFF movement, interviewee's background, and their ideas regarding politics, democracy, and political participation. Particular focus was here paid to the parts of the interview where the interviewees discussed political participation and their perceptions of democracy. The material was analyzed by using theory-guided content analysis (Krippendorff, 2012), which focuses on the interviewees' conceptions of and ideas on participation. In the analysis, a key goal was to identify what kind of factors and themes the respondents themselves emphasized as important when discussing political participation, and what themes were repeated throughout the interviews. These factors and themes were then compiled and matched with the theoretical framework to identify what conceptions of participation they adhere to.

This study was conducted in accordance with The Finnish National Board on Research Integrity TENK's "Ethical principles of research in the humanities and social and behavioral sciences and proposals for ethical review", 6 which researchers operating in Finland must comply to when conducting research with human participants. In addition, this study and article is written in accordance with TENK's "guidelines for the responsible conduct of research and for handling alleged violations of conduct", which promotes the responsible conduct of research.

\section{RESULTS}

In many ways, the global climate activists appear to be poster children for the idea of cause-oriented young people (e.g., Kimberlee, 2002; Chou, 2017) who participate in more direct, active and engaged ways to influence political matters. Therefore, it would be plausible that these young people have a more participatory perspective on their political engagement. However, a further examination within the Finnish FFF activists paints a more complex picture of the ideas these young activists have in regards to political participation.

The material from the interviews were compiled together and matched with the theoretical framework. After compiling the material, it became clear that certain specific attitudes toward political participation and democracy were repeated in most interviews. Despite the expectation that these young citizens will display more participatory preferences-that the Finnish FFF activists prefer more opportunities for active and direct citizen involvement in political processes instead of participation in the institutionalized forms of engagement-two perspectives regarding political participation and democracy rose from the material. In the Finnish context:

${ }^{6}$ For more information on the guidelines: www.tenk.fi/en
Activity in the FFF movement does not necessarily equal support for more citizen participation in general.

Activity in the FFF movement does not mean rejection of established democratic norms, practices or political authorities.

Despite the differences in interviewees' age and level of engagement in the movement, these two perspectives were evident throughout the material. Below, these perspectives are explained further.

\section{Activity in The FFF Movement Does Not Necessarily Equal Support for The More Citizen Participation in General}

The global FFF movement uses rhetoric such as 'we should not have to be here', referring to the climate strikes, while demanding adults and politicians to take political responsibility for the problem that they have caused. As the movements' leading figure, Greta Thunberg stated in her speech for the UN in 2019:

\begin{abstract}
My message is that we'll be watching you. This is all wrong. I shouldn't be up here. I should be back in school on the other side of the ocean. Yet you all come to us young people for hope. How dare you. You have stolen my dreams and my childhood with your empty words. Yet I am one of the lucky ones. People are suffering. (NPR Staff, 2019)
\end{abstract}

The Finnish leading climate activists' Atte Ahokas's had a similar message in an interview with The Finnish Public Service Media Company Yle:

We young people shouldn't be here. It is not our job to tell how this crisis will be solved. We are here to demand that adults begin to do their jobs. (Tola, 2019)

This type of public statements already suggest that the participatory perspective might not be able to explain mobilization in the FFF movement since leading FFF figures do not demand more citizen participation or more possibilities for direct citizen participation for the young, instead they are highlighting adult responsibility to act. Instead of more participatory options for the young, their message behind the reasons for involvement in the FFF movement is that the issue of climate change is too important for them and they feel obliged to act. As Pickard suggest, youth-led protest actions can be made out of necessity and sense of injustice (Pickard, 2019, p. 380).

In the interviews conducted with the Finnish FFF participants, following types of reasoning were highlighted when the interviewees talk about their motivation for participation in the movement:

Most what motivates and the reason why I want to influence is future and the threat that if we don't start to do any actions then that future is gone. And especially I am most worried about my children and 
grandchildren's future, they don't even have anything to do, no chance to affect their future.-if we want to live on this earth, we have to take action.

Well somehow have just started to wake up that our age class and like life's biggest crisis that like has to get solved somehow or even slowed down even a little bit so that we can live, and our future generations can live on earth. Because this is a crisis so soon there is nothing that can be done.

Even though I myself already have the right to vote, not all young people have it yet and I want to somehow show to the decision-makers that this really is a really important thing and like this cannot be swept to the side this is really about like my generations like future in these climate, like if climate actions are not done like ambitiously enough.

The interviewed Finnish activists are not participating because they necessarily want to be more actively involved in politics in general. Instead of an inherent desire for more citizen participation, or wish to participate in a broader repertoire of political actions, the Finnish FFF activists are taking to the streets because they feel the need to defend their and future generations' rights to a habitable planet, threatened by the climate crisis. The interviewees feel that the issue is currently not taken care of by the decision-makers. In the interviews, they highlight ideas that are corresponding to Pickard's (2019, p. 377) argument: the young are turning to this form of non-electoral political action because they are disappointed with the formal political system and politicians, who have failed the young in the fight against global warming. The interviewees are not willing to give decision-makers the opportunity to be self-serving (Hibbing and Theiss-Morse, 2002), but rather they are willing to participate when the need arises and they want their demands to be heard by formal political decision makers. The dissatisfaction with the established formal system (see Pickard, 2019, p. 377), and the stealth democratic concept of participation as a way to take power away from self-serving politicians (Hibbing and Theiss-Morse, 2002), seem to motivate the participation in the FFF movement instead of an inherent desire for more citizen participation.

Even though the interviewees do not seem to have participatory preferences, they do want to be heard. Some system-level theories on youth disengagement in politics explain that one reason for young people's non-participation can be due to politicians' failures to address issues that are of importance or concern for young people, such as the climate change (Henn et al., 2002; Kimberlee, 2002). For these Finnish climate activists the opposite seems to be true: they are activated by politicians' failures and willing to use their activity to influence political change.

Further support for the argument that activity in the FFF movement does not equal support for the participatory perspective can be found in the interviewed activists' attitudes toward the options for political activity at their disposal. The majority of the interviewees said that they are happy with the opportunities they have and that they do not want more possibilities for participation. Despite stating that they are interested in politics and that they see politics as something important, many felt that they, and citizens in general, had enough options for political participation if they wanted to use them.

But like at the moment the kind of activities I know I don't really come up with the kind I would want to get involved with. If I wanted to participate in young people's political activities, I would probably already have participated.

And like maybe that possibilities for influencing would be pretty similar since I don't really know how to do better.

So I think the way people can influence politically at the moment is good, but I feel like people don't use it like right. Or like somehow care enough about the things so that they would for example affect through consumption, they're just like I am just one person what difference does it make but if a lot of people think so so yes it's a little. Not so much that I would change the means of my political influence, but I would change what people think about political influence.

Those of the interviewees who were not happy with the kind of options for political activity that they had generally wanted to lower the voting age to 16 . This indicates that instead of fostering participatory values, the Finnish FFF activists actually support representative democracy, even if they want it to be more inclusive of and more attentive to the demands of younger citizens.

In contrast to the participatory perspective, a different interpretation holds that even if young people do participate in participatory forms of politics, engagement in such activities is not driven by an inherent desire to be active in politics but rather out of necessity, e.g., in order to take power away from selfserving politicians (Hibbing and Theiss-Morse, 2002, p. 130). Thus, all young citizens' activity cannot automatically be interpreted as a desire for more participatory options for citizens in politics. The interviews suggest that in Finland the activity in the FFF movement does not necessarily equal support for more participatory forms of political engagement, rather the young activists want to participate in the institutionalized forms of politics. This is notable, as it contrasts e.g., studies made in Britain where the local FFF activists are committed to systemic change through non-violent direct action (Pickard et al., 2020).

\section{Activity in The FFF Movement Does Not Mean Rejection of Established Democratic Norms, Practices or Political Authorities}

The Finnish young climate activists do not seem to have more participatory preferences. Instead, they might support the representative system more than expected. The Finnish interviewees display a great support for the representative 
system, as voting is considered by far the best way to influence politics among the young activists. The interviewees' age and whether or not they were eligible to vote or not did not have an effect on the popularity of elections as the best way to influence politics. Instead of being active themselves, these young climate activists seem to want to participate politically by electing politicians, who will represent them and their interest in the decision-making processes. As one interviewee put it:

You vote for a person who is as similar as you as possible, they bring your voice out there in Parliament. The most important and biggest way you can make a difference.

Activity in the FFF movement does not mean that these Finnish climate activists reject established democratic norms, practices or political authorities. Instead, their ideals come across as being consistent with the ideal of a well-functioning representative democracy. The interviewees believe that their vote matters, that politics and political decision-making are affected by citizens' votes and that election participation is important. This is highlighted by the answers given to the question why voting is the best way to influence, for example:

Well because there are so many of us here and everyone really has one voice and one voice is really meaningful to me and in a way it's probably the easiest way to get things right. And what can really make a big difference if people only vote, especially if young people vote. So that is maybe what comes to mind first.

Go to the polls. What does it matter, it does matter. Vote and doing the research [of candidates]. ${ }^{7}$ They are the best ways [to influence politics].

Not only did the interviewees believe their vote matters, they also based the importance of election participation on normative grounds. As one interviewee highlighted:

But some basic doctrines have been forged in the head at home. Environmental issues are important. Voting is important.

Other explanations in support of voting provided by the interviewees ranged from 'it is the least you can do' and 'someone might say does it matter, well it does matter', to the classic arguments 'if you do not vote, you cannot complain' or 'if you do not vote, someone else (read: an older person) will vote for you'. In general, despite their activity in a protest movement and using civil disobedience to further their political demands, the interviewees were not rejecting established representative norms. Rather, they were enforcing them by the usage of classic arguments used to highlight the importance of election participation.

${ }^{7}$ To clarify the quote by the interviewee, the author has added the brackets.
The interviewees do not seem to reject political authorities either. As the FFF movement is a protest movement, that uses civil disobedience to further their demands, it would be plausible that activity in the FFF movement would mean rejection of political authority. The rejection of political authorities would essentially entail that through their activity in the FFF movement the participants want to diminish the power of political authorities. However, the interviewees are participating in the climate strikes in order to convince the decision-makers into action, therefore displaying support for the political authorities and their capability and desire to act on the demands of young climate activists. The support for political authorities that the Finnish interviewees display may be due to the leftishgreen government taking power shortly before the interviewees were conducted, as the interviewees might be more positively inclined toward decision-makers they believe to be favorable for their demands. However, as social movement studies suggest, it is typical for social movement activists to try to operate in existing political processes and influence and demand responsibility from the policymakers (Kriesi, 2004; Thörn and Svenberg, 2016), regardless of who is in power.

The idea of FFF protesters not rejecting authority can find support from other channels in general as well. The 'Youth climate strikers' open letter to world leaders', which was issued by the global coordination group of the youth-led climate strike ahead of the international climate strike day March 15th and published by Guardian, says:

We demand the world's decision-makers take responsibility and solve this crisis. You have failed us in the past. (Guardian Letters, 2019)

Despite stating that the politicians have failed the young, in this letter the FFF movement's global coordination group is not demanding power away from politicians, and thereby rejecting authority, but rather the writers try to appeal to political authorities to solve the climate crisis. Instead of rejecting the authorities, they are leaning on the authorities to solve the issue (Hibbing and Theiss-Morse, 2002, p. 13). In the Finnish context, similar sentiments can be found in interviews given by climate strike participants in the largest newspaper in the country, Helsingin Sanomat (HS):

We do not expect the laws to be changed immediately due to our demonstration, but we want decision-makers to listen and pay attention (Vuorio, 2019)

Decision makers make big decisions that everyone has to follow. They make laws. They have a bigger voice than I do and that is why it is important that they hear my voice (Takala, 2019)

Previous research done on the FFF movement supports the sentiment that the participants in the FFF movement want authorities to take action to resolve the issue-they are on the streets to put pressure on politicians, not to override them. Wahlström et al. (2019) research from international 
climate march in March 2019 demonstrate that the FFF participants wanted to influence particularly politicians: they regarded their participation as a way 'to pressure politicians to make things change' $(91.1 \%$ agree or strongly agree). As the FFF participants are putting their faith in politicians through their political activity, the activity in the FFF movement cannot be seen to equal rejection of authorities.

Despite not rejecting authority, the interviewed Finnish FFF participants want politicians to listen to their demands better. Variety of research demonstrates that young people feel that they are not being heard by politicians, or that they feel like they cannot influence politics (e.g., Henn et al., 2002; Kimberlee, 2002; O'Toole et al., 2003; Quintelier, 2007). The Finnish interviewees have a complex relationship with the authorities. These climate activists feel that even though politicians might listen, they do not hear young people's demands and they fail to take appropriate action:

At the moment, the vast majority are like they might say that they support the goal of one and a half degrees, but they are not ready for the action it requires and have not yet begun to do so even though we have been demanding it in large numbers.

Hearing and listening is different. The politician might hear you, they can be told, they can be there, they can say something but I think, it can even be listening, but at this point I'm going to be happy with the amount of listening when we get something other than a newspaper article about how a politician say it is great thing that young people are moving. When it is visible in their decisions.

They are interested [in what young people have to say] but they believe that young people are not going to vote. That is why many politicians are more interested in retirees' issues, they are active voters. In the next election, we are in our twenties and then they can become maybe more interested, more serious, so that politicians also get young voters.

These examples show that the Finnish FFF participants want to be heard and they want decision-makers to do adequate climate actions. Through active participation, the interviewees felt that they were pressuring politicians into hearing young people's demands and voices.

\section{DISCUSSION}

Based on the ideas regarding political participation and democracy that the interviewed Finnish FFF participants demonstrate, I argue that the young activists, despite their evident involvement in a major, global protest movement, do not display more participatory preferences when it comes to political decision-making, nor are they rejecting established democratic norms, practices, or political authorities. Instead of wanting more direct and active citizen participation in non-institutionalized forms of political engagement, the Finnish FFF activists prefer a better functioning representative system.

The different forms of political participation are not mutually exclusive: the young can participate in multiple ways at the same time, both in single-issue movements and by voting, and the different forms can form a positive cycle of political engagement (Pickard, 2019, p. 397). However, young people's lack of election participation is often explained by their more participatory preferences (see the literature review). Especially groups of active young people are expected to foster a more participatory perspective on democracy and political participation, when they have become active in a single-issue movement. In the case of Finnish FFF participants, however, the participation in a protest movement does not appear to mean rejection of electoral politics-rather the interviewees see the value in voting. The results demonstrate that the involvement in the FFF movement may be driven by a sense of immediate urgency rather than a demand for a fundamental transformation of democracy: these young people participate out of necessity-to ensure that the decision-makers do a decent job in an important political question. Borrowing from Pickard (2019), this case study supports the idea that "the nature of young people's nonelectoral participation tends to be personalized (i.e., tailor made or custom-built) according to circumstances and values, rather than moved by self-centered benefits" (2019, p. 397). The Finnish FFF participants have chosen the FFF movements' protest activities as their form of political participation because they feel they are not being heard by decision-makers otherwise, not because it necessarily fits their preferences and ideals for participation. In addition, these findings support the notion that the political opportunity structures (Kriesi, 2004) affect the form of political engagement employed by participants of social movements. As many of the Finnish FFF activists are minors without the right to vote, the movement's activities provide them opportunities to demand responsibility from decisionmakers in the issue of climate change, without necessarily revealing anything about their preferences for political engagement. This is one reason, why these kind of qualitative studies that deepen our understanding on the topic of young people's ideas regarding democracy and political participation are important.

These findings can have important implications for the future of Finnish democracy. When even the most-likely case of young people support the existing representative system over more participatory options, it shows that the classic representative democratic system still plays a vital and important role, even for those young people who are active in a protest movement. What is demanded is not a radical transformation, but mechanisms to ensure that politicians remain attentive to the demands of younger citizens. The Finnish FFF activists do not demand a revolution, but they want politicians to do their job better 
and work to ensure a viable future even for younger generations. Instead of more participatory options for the young, a viable reform option may be lowering the voting age to 16 since similar reforms have successfully engaged younger citizens elsewhere (e.g., Wagner et al., 2012)

These findings have limitations. It is not possible to make broad generalizations based on this limited data. Also, despite the FFF movement's wide popularity even in Finland, the climate activists only make up for a small part of the current young generation and we know that socioeconomic factors such as class, education, and gender affect political participatory habits and preferences among young people (e.g., Henn and Foard, 2014; Chou, 2017). Previous global quantitative research shows that the activists are in general well-educated (Wahlström et al., 2019) and this holds true also for the participants in this study. Additionally, it is possible that the Finnish activists' positive attitude toward representation and the emphasis they put on the role of elections might be an effect of elections proximity, as the parliamentary elections were held shortly before the interviews were conducted, but also the election outcome. Perhaps the young activists have more trust in the new leftish-green government that took office in spring 2019, to handle climate issues and to respond to activists' demands, which is why they are seemingly not rejecting authority when it comes to their ideas regarding political participation. In future studies, in order to deepen our knowledge on the issue, studies with a larger and more representative sample could provide additional insights.

\section{REFERENCES}

Bengtsson, Å., and Christensen, H. S. (2016). Ideals and Actions: Do Citizens' Patterns of Political Participation Correspond to Their Conceptions of Democracy? Govern. Oppos. 14, 1-27. doi:10.1017/gov.2014.29

Bengtsson, A. (2012). Citizens' Perceptions of Political Processes. A Critical Evaluation of Preference Consistency and Survey Items. Revista Internacional de Sociología 70 (2), 45-64. doi:10.3989/ris.2012.01.29

Bengtsson, Å., and Mattila, M. (2009). Direct Democracy and its Critics: Support for Direct Democracy and 'Stealth' Democracy in Finland. West Eur. Polit. 32 (5), 1031-1048. doi:10.1080/01402380903065256

Bennett, W. (2008). "Changing Citizenship in the Digital Age," in Civic Life Online: Learning How Digital Media Can Engage Youth. Editor W. Bennet (Cambridge, MT: MIT Press), 1-24.

Cammaerts, B. (2012). Protest Logics and the Mediation Opportunity Structure. Eur. J. Commun. 27 (2), 117-134. doi:10.1177/0267323112441007

Chou, M. (2017). "Disengaged, Young People and Political Disengagement in Anglo-American Democracies," in Young People, Citizenship and Political Participation: Combating Civic Deficit? Editors M. Chou, J-P. Gagnon, C. Hartung, and L. Pruitt (London, UK: Rowman \& Littlefield Publishers).

Dalton, R. J., Bürklin, W. P., and Drummond, A. (2001). Public Opinion and Direct Democracy. J. Democracy 12 (4), 141-153. doi:10.1353/jod.2001.0066

Dalton, R. J. (2008). Citizenship Norms and the Expansion of Political Participation. Polit. Stud. 56 (1), 76-98. doi:10.1111/j.1467-9248.2007. 00718.x

Dalton, R. J. (2007). Partisan Mobilization, Cognitive Mobilization and the Changing American Electorate. Elect. Stud. 26 (2), 274-286. doi:10.1016/j. electstud.2006.04.009

Dalton, R. J. (2016). The Good Citizen: How a Younger Generation Is Reshaping American Politics. Thousand Oaks, CA: SAGE Publications.

Delli Carpini, M. X. (1989). “Age and History: Generations and Socio-Political Change," in Political Learning in Adulthood. Editor R. Siegel (Chicago: University of Chicago Press), 11-56.

\section{DATA AVAILABILITY STATEMENT}

The raw data supporting the conclusions of this article will be made available by the authors, without undue reservation.

\section{ETHICS STATEMENT}

Ethical review and approval was not required for the study on human participants in accordance with the local legislation and institutional requirements. Written informed consent from the participants' legal guardian/next of kin was not required to participate in this study in accordance with the national legislation and the institutional requirements.

\section{AUTHOR CONTRIBUTIONS}

The author confirms sole responsibility for the following: study conception and design, data collection, analysis and interpretation of results, and manuscript preparation.

\section{FUNDING}

Ãbo Akademi University's APC-Pool supported the open access publication of this article.

Dinas, E. (2013). Opening “Openness to Change”. Polit. Res. Q. 66 (4), 868-882. doi: $10.1177 / 1065912913475874$

Farthing, R. (2010). The Politics of Youthful Antipolitics: Representing the 'issue' of Youth Participation in Politics. J. Youth Stud. 13 (2), 181-195. doi:10.1080/ 13676260903233696

Furlong, A., and Cartmel, F. (2007). Young People and Social Change: Individualisation and Risk in Late Modernity. 2nd ed. Maidenhead: Open University Press.

George, A. L., and Bennett, A. (2005). Case Studies and Theory Development in the Social Sciences. Cambridge, MT: MIT Press.

Grasso, M. T., Farrall, S., Gray, E., Hay, C., and Jennings, W. (2018). Socialization and Generational Political Trajectories: An Age, Period and Cohort Analysis of Political Participation in Britain. J. Elections, Public Opin. Parties 29, 199-221. doi:10.1080/17457289.2018.1476359

Guardian Letters (2019). Climate Crisis and a Betrayed Generation. Available at: https://www.theguardian.com/environment/2019/mar/01/youth-climatechange-strikers-open-letter-to-world-leaders

Hammarberg, K., Kirkman, M., and De Lacey, S. (2016). Qualitative Research Methods: when to Use Them and How to Judge Them. Hum. Reprod. 31 (3), 498-501. doi:10.1093/humrep/dev334

Henn, M., and Foard, N. (2014). Social Differentiation in Young People's Political Participation: the Impact of Social and Educational Factors on Youth Political Engagement in Britain. J. Youth Stud. 17 (3), 360-380. doi:10.1080/13676261. 2013.830704

Henn, M., Weinstein, M., and Wring, D. (2002). A Generation Apart? Youth and Political Participation in Britain. The Br. J. Polit. Int. Relations 4, 167-192. doi:10.1111/1467-856X.t01-1-00001

Hibbing, J., and Theiss-Morse, E. (2002). Stealth Democracy. Americans' Beliefs about How Government Should Work. Cambridge: Cambridge University Press. doi:10.1017/cbo9780511613722

Huttunen, J., and Christensen, H. S. (2020). Engaging the Millennials: The Citizens' Initiative in Finland. Young 28 (2), 175-198. doi:10.1177/ 1103308819853055

Inglehart, R. (1997). Modernization and Postmodernization: Cultural, Economic and Political Change in 43 Societies. Princeton: Princeton University Press. 
J. de Moor, K. Uba, M. Wahlström, M. Wennerhag, and M. De Vydt (Editors) (2020). "Protest for a Future II: Composition, Mobilization and Motives of the Participants in Fridays for Future Climate Protests on 20-27 September, 2019, in 19 Cities Around the World", Available at: https://www.researchgate.net/ publication/339443851_Protest_for_a_future_II_Composition_mobilization_ and_motives_of_the_participants_in_Fridays_For_Future_climate_protests_ on_20-27_September_2019_in_19_cities_around_the_world (Accessed Jan 05, 2021).

Kimberlee, R. H. (2002). Why Don't British Young People Vote at General Elections?. J. Youth Stud. 5 (1), 85-98. doi:10.1080/13676260120111788

Kriesi, H. (2004). "Political Context and Opportunity," in The Blackwell Companion to Social Movements. Editors D. Snow, S. A. Soule, and H. Kriesi (MA, Oxford, Victoria: Blackwell Publishing Ltd), 67-89.

Krippendorff, K. (2012). Content Analysis: An Introduction to its Methodology. Thousand Oaks, CA: Sage.

Marquardt, J. (2020). 'Fridays for Future's Disruptive Potential: An Inconvenient Youth between Moderate and Radical Ideas'. Front. Commun. 5 (48), 114. doi: $10.3389 /$ fcomm. 2020.00048

Myllyniemi, S. (2014). Vaikuttava Osa. Nuorisobarometri 2013. Helsinki: Hakapaino.

NPR Staff (2019). Transcript: Greta Thunberg's Speech at the U.N. Climate Action Summit. Available at: https://www.npr.org/2019/09/23/763452863/transcriptgreta-thunbergs-speech-at-the-u-n-climate-action-summit? $\mathrm{t}=1583500021835$.

O'Toole, T., Lister, M., Marsh, D., Jones, S., and McDonagh, A. (2003). Tuning Out or Left Out? Participation and Non-participation Among Young People. Contemp. Polit. 9 (1), 45-61. doi:10.1080/1356977032000072477

Pickard, S., Bowman, B., and Arya, D. (20202020). "We Are Radical in Our Kindness": The Political Socialisation, Motivations, Demands and Protest Actions of Young Environmental Activists in Britain. Youth Glob. 2, 251-280. doi:10.1163/25895745-02020007

Pickard, S. (2019). Politics, Protest and Young People. Political Participation and Dissent in 21st Century Britain. London: Palgrave MacMillan. doi:10.1057/9781-137-57788-7

Pontes, A., Henn, M., and Griffiths, M. (20182018). Towards a Conceptualization of Young People's Political Engagement: A Qualitative Focus Group Study. Societies 8 (1), 17. doi:10.3390/soc 8010017

Quintelier, E. (2007). Differences in Political Participation between Young and Old People. Contemp. Polit. 13 (2), 165-180. doi:10.1080/13569770701562658

Quintelier, E., and Van Deth, J. W. (2014). Supporting Democracy: Political Participation and Political Attitudes. Exploring Causality Using Panel Data. Polit. Stud. 62 (1), 153-171. doi:10.1111/1467-9248.12097

Stoker, G. (2006). Why Politics Matters, Making Democracy Work. New York: Palgrave Macmillan.
Takala, A. (2019). Aikuisten saamattomuuteen tuskastuneet nuoret lakkoilivat ilmaston puolesta, Eduskuntatalolla parveili satoja nuoria - "Tässä on meidän tulevaisuudesta kyse". [Young people irritated with adult's inefficiency were on a strike for climate, hundreds of young people swarm the Parliament house "This is about our future".] Helsingin Sanomat. Available at: https://www.hs.fi/ kaupunki/espoo/art-2000005962180.html.

TENK (2013). Responsible Conduct of Research and Procedures for Handling Allegations of Misconduct in Finland. Guidelines of the Finnish Advisory Board on Research Integrity 2012.

Thörn, H., and Svenberg, S. (2016). 'We Feel the Responsibility that You Shirk': Movement Institutionalization, the Politics of Responsibility and the Case of the Swedish Environmental Movement. Soc. Move. Stud. 15 (6), 593-609. doi:10. $1080 / 14742837.2016 .1213162$

Tola, T. (2019). Atte, 16, on Ilmastolakkoillut Jo Vuoden-Aikuinen, Olisiko Sinunkin Aika Tehdä Jotain? Atte, 16, Has Already Been Climate Striking for a Year-Adult, Would it Be Also Your Time to Do Something? Available at: https://yle.fi/uutiset/3-10973068

Vuorio, J. (2019). Aikuiset ovat saamattomia, joten lukiolaiset ryhtyvät perjantaina lakkoon ilmaston puolesta - Rehtori: "Lakko on väärä keino" [The adults are inefficient so high-schoolers will be striking for the climate on Friday Headmaster: "A strike is a wrong means"]. Helsingin Sanomat. Available at: https://www.hs.fi/kaupunki/art-2000005960512.html.

Wagner, M., Johann, D., and Kritzinger, S. (2012). Voting at 16: Turnout and the Quality of Vote Choice. Elect. Stud. 31 (2), 372-383. doi:10.1016/j.electstud. 2012.01.007

M. Wahlström, P. Kocyba, M. De Vydt, and J. de Moor (Editors) (2019). Protest for a Future: Composition, Mobilization and Motives of the Participants in Fridays for Future Climate Protests on 15 March, 2019 in 13 European Cities. Available at: https://www.researchgate.net/publication/334745801_Protest_ for_a_future_Composition_mobilization_and_motives_of_the_participants_ in_Fridays_For_Future_climate_protests_on_15_March_2019_in_13_European_ cities.

Conflict of Interest: The author declares that the research was conducted in the absence of any commercial or financial relationships that could be construed as a potential conflict of interest.

Copyright (c) 2021 Huttunen. This is an open-access article distributed under the terms of the Creative Commons Attribution License (CC BY). The use, distribution or reproduction in other forums is permitted, provided the original author $(s)$ and the copyright owner(s) are credited and that the original publication in this journal is cited, in accordance with accepted academic practice. No use, distribution or reproduction is permitted which does not comply with these terms. 